$\begin{array}{ccc}\text { Tentham open } & \text { The Open Automation and Control } \\ \text { CrossMark } & \text { Systems Journal } \\ \text { Content list available at: www.benthamopen.com/TOAUTOCJ/ } & \text { DOI: } 10.2174 / 1874444301608010004\end{array}$

\title{
Retraction Notice: Virtual Laboratory Construction of College Computer Hardware Course Group
}

\author{
Wang Haiyan * \\ Department of Information Engineering, Binzhou University, Binzhou. Shandong, 256600, China
}

\section{RETRACTION}

The Publisher and Editor have retracted this article [1] in accordance with good ethical practices. After a thorough investigations we believe that the peer review process was compromised. The article was published on-line on 14-09-2015.

\section{REFERENCE}

[1] Haiyan W. Virtual laboratory construction of college computer hardware course group. Open Autom Control Syst J 2015; 7: 1237-42.

(C) Wang Haiyan; Licensee Bentham Open.

This is an open access article licensed under the terms of the Creative Commons Attribution-Non-Commercial 4.0 International Public License (CC BY-NC 4.0) (https://creativecommons.org/licenses/by-nc/4.0/legalcode), which permits unrestricted, non-commercial use, distribution and reproduction in any medium, provided the work is properly cited.

\footnotetext{
* Address correspondence to these authors at the Department of Information Engineering, Binzhou University, Binzhou. Shandong, 256600, China; Tel: +8618935963567; E-mail: wanghaiyanhy57@163.com
} 